\title{
Building Employer Image Thanks to Talent Programmes in Czech Organisations
}

\author{
Lucie Vnouckova $^{1}$, Hana Urbancova ${ }^{2}$, Helena Smolova ${ }^{3}$ \\ ${ }^{1,3}$ University of Economics and Management \\ Prague 5, 15800 Prague, Czech Republic \\ E-mail.lucie.vnouckova@vsem.cz,helena.smolova@vsem.cz. \\ ${ }^{2}$ Czech University of Life Sciences Prague \\ Town: Prague 6, 16521 Prague, Czech Republic \\ E-mail.urbancova@pef.czu.cz. \\ cross $^{\text {ref }}$ http://dx.doi.org/10.5755/j01.ee.29.3.13975
}

\begin{abstract}
With regard to the fact that human resources have become the greatest competitive advantage of organisations, Czech organisations make efforts to create and continuously vary the talent programmes which they offer to their employees. When joining such programmes, employees can deepen their existing knowledge, acquire new knowledge and develop their abilities and skills. The goal of the article is to identify the approaches of using talent programmes in the Czech Republic, which lead to building of the employer image. The sub-goal is to test defined hypotheses in order to formulate recommendations of applicable approaches to work with talents. The results were achieved by the means of quantitative research $(n=134)$ carried out among employees of organisations who take part in a talent programme. For the purposes of testing, the Pearson's chi-square test and the association test were employed. The results show that there exists a difference in the talent programme placement between managers and employees $(p=0.027)$. The other characteristics are not significant for the selection of a talent programme. Additionally, multidimensional statistics were used to find two types of organisations related to the use of talent programmes to build employer's image. First type are the organisations focused on HR marketing, and the second typye - lacking transparency in employer branding. The outputs alow us to define crucial components of succesfull employer branding. The paper contains an in-depth discussion of the concept of building employer image as well as identifies the main determinants connected with it. Moreover, the paper presents new research findings by defining and validating the main attributes of the employer image. The limits of the article can be deemed to consist in a relatively small sample of respondents; however, with respect to the exclusive approach to the talent management in the Czech Republic, the sample can be described as sufficient.
\end{abstract}

Keywords: Talent Management; Creativity; Employee; Talent Programme; Human resources; Development.

\section{Introduction}

In all the developed countries, human resource management is considered a key area of management, vital for the success of every organisation. Organisations cannot work without qualified employees, thus, human resource management becomes a cornerstone for the functioning of organisations. Human resource management can be understood as a system of linked methodologies and decision-making, the purpose of which is management and development of the human potential for organisations to achieve their strategic objectives; however, it is also necessary to respect employees' requirements and aspirations and it is important for every organisation, regardless of its size or sector of economy.

Talent management can be regarded as a systematic approach to appointing the right people to the right positions at the right time. It can be said that to employ talented staff is the aim of every employer, since both performance of organisations and their economic success are always dependent on knowledge, abilities and skills of their employees. Therefore, management teams of the organisations strive to be good at correctly identifying talents and subsequently developing them in effectively designed talent programmes. The opportunity to develop should be given not only to a selected group of employees (exclusive approach), for example according to the time of employment, age, or specific position in an organisation, but also to all talented employees in all positions in the organisation (inclusive approach). Talent programmes should be based on previous analyses of the development need identification with the emphasis on creativity development as an instrument of well- and wrong-structured problem solving at an optimum time and with positive results.

Kocianova (2012) says that at present many talent management programmes build on competency models that help staff to direct their talents based on identified requirements of their organisation. The main examples of talent programmes that are used in the Czech Republic are trainee programmes (for school-leavers/graduates or employees who are in the organisation for a rather short time) and programmes for the development of managers and other institutional staff. Hroník (2007) distinguishes talent programmes by their focus on general aspects, such as managerial skill development, and on special aspects, including specific skill development. Kocianova (2012) points out that these programmes should have fixed criteria for selecting talents, including evaluation methods, and it 
is equally necessary not to forget to engage managers, mentors and coaches.

Jain and Bhatt (2014) claim that the perceived significance of employer branding factors differs mainly across gender and age of prospective employees. Demographic changes bring about a possible problem with negative ageing situation of employees in organisations, and the lack of successors from the group of talented employees plagues the economies around the world. In this context, we can see a significant milestone of social responsibility of organisations which points to an active approach to employees and to talent management application. It is important to realize that the problem of lack of talents will have to be solved using alternative sources with emphasis on the specific target groups (particularly women, seniors, immigrants, ethnic groups which are underrepresented among the workers). Aging workforce and the loss of knowledge workers are considerable threats for organisations, not only in terms of the loss of performance, but also the loss of the organisational knowledge. To control the demographics the future will probably engage the procedures in a form of internal or multidisciplinary learning and training to improve qualifications. Also, the age of employees should not be a barrier to inclusion in the talent programmes of organisations.

It can be concluded that talent management is currently becoming an increasingly important part of human resource management, and organisation management teams in the Czech Republic realise more than ever that if they want to succeed among their competitors it is important to have efficient employees who have a potential, creative thinking and talent. Organisations who want to prosper and leave their competitors behind have to identify talented individuals, attract and develop them and, last but not least, retain them. For this reason, it is important for the organisations to pay attention to the design and continuous modification of their talent programmes and motivate employees to develop as much as possible. Employees satisfied with the defined talent programme which they have joined will see benefits for their development and their creativity will not be inhibited. As a result of that, they will not tend to leave for competitors and will continue contributing to the accomplishment of strategic objectives of the organisation.

Swailes and Blackburn (2016) identified two threats deriving from establishing a talent programme: the depression of excluded employees and failure to sustain positive effect among the included employees. Flahive (2015) says that the right programme is targeted at people who predominantly engage in people management responsibilities and accents that typically the participants in talent programme have between 5 to 10 years of relevant work experience and less than 5 years of relevant management experience. According to Kwon (2014), preparation of motivation talent programme is important primarily across financial services sectors, but it is also important in every sector and business nowadays, as supported by Vnouckova et al. (2015). Malik and Singh (2014) state that the level of motivation is important in forming employee attitudes to talent programmes, which then affects his/her commitment and organisational citizenship behaviour.
In daily work, each employee faces problems that need to be solved, but in the current competitive environment it is always necessary to come up with new, original and creative ideas of how to solve problems. Talent programmes can facilitate employees' creativity development, as it is one of the most appreciated qualities of employees in the Czech labour market.

The goal of the article is to identify the approaches of using talent programmes in the Czech Republic, which lead to building of the employer image. The sub-goal is to test defined hypotheses in order to formulate recommendations of applicable approaches to work with talents. In particular, the article strives to determine whether there are any differences or dependencies among the types of employees and their placement in talent programmes, and their creative approaches to work in the organisation.

The structure of the paper is as follows: the theoretical background of the work is presented first; this is followed by methodology which describes the preparation of the paper. Furthermore, the results have been evaluated and we have proposed a summary and recommendations deriving from the research. Finally, the paper also presents the theoretical and practical benefits and limitations which apply to it.

\section{Theoretical Background}

Collings and Mellahi (2009) define talent management as activities and processes which are related to the systematic identification of key positions, development of the talent pool, as well as the development of differentiated human resource architecture. This is all done in order to facilitate the matching of the right employees with the right job, as well as to ensure their connection and commitment to the organisation. Silzer and Dowell (2010) add that this concept shows talent management to be a key organisational process ingrained in the whole organisation. It is possible to view talent management similarly as a method for defining talent in organisations (Garavan, Carbery and Rock, 2012).

Brewster, Sparrow and Harris (2005), Dell and Hickey (2002) or Deb (2006) emphasize the interconnections between talent management and building of the employer's strong and positive image thanks to which talented individuals may be attracted and retained. According to Chapman et al. (2005) the concept of employer image building depends directly on talent management because it represents a combination of various HR approaches influencing the future reputation of the company as an employer. Building of the employer image may thus help resolve the worldwide lack of talented individuals (Jiang and Iles, 2011).

Jain and Bhatt (2015) state that the concept of employer image building has thus emerged as an essential management practice employed by the organisation to create its image as desirable employer in the eyes of prospective employees. Edwards and Edwards (2013) state that building of employer image is very important field of human resources nowadays for every organisation. Love and Sing (2011) claim that the concept of employer image bulding is a valuable asset and a key factor of success, and Martin et al. (2011) add that successful building of the employer's image helps organisations win the war for 
talents and solve personnel problems. We can summarize that the concept of employer image building is becoming an increasingly important topic for research and practice in all organisations independently of size of organisation because it is directly linked with their organisation reputation, talent management, and employee engagement activities. The results of the research of Burawat (2015) show that there are strong positive relationships between perceived employer branding and employee engagement, perceived employer branding and employee expectation, and employee expectation and employee engagement.

Backhaus and Tikoo (2004) state that building of the employer's image represents an organisation's efforts to promote, both within and outside the organisation, a clear view of what makes it different and desirable as an employer, and they added it brings a number of benefits, for example it reduces employee turnover, improves opportunities for getting new high-quality employees (Sonnenberg et al., 2013), increases the satisfaction of current employees and enhances performance of the organisation, which is also confirmed by Sturman et al. (2012), Mohr et al. (2012) and Farndale et al. (2014).

Kim et al. (2011) say the concept of employer image building requires that a pre-set process must be supported by top management and must be correctly formulated in strategy of organisation. If the internal and external presentation of an organisation is poor, it will discourage talented candidates from the labour market and demotivate our employees from development. Festing and Schäfer (2014) state that for talent retention it is very important to solve employee motivation and psychological-contract perspective in organisations. Mpofu and Hlatywayo (2015), on the basis of their survey, state that incentives that could motivate employees to take part in employee training and development include the prospect of promotion or the provision of clear hierarchies in the organisation so as to indicate where performance is rewarded.

According to the above mentioned we can summarize that talent management is a valuable human resource activity which supports building employer's image by tools of personnel marketing, effectively uses the whole potencial of each employee, and leads to the competitive advantage, as confirmed by Fernandez-Lores et al. (2016). Wilden et al. (2010) add that, as a result of growth of competition in the labour market, strategic investments in the recruitment of suitable talented human resources are a must and the concept of employer image building contributes to that. They confirm the building of the employer's image is an issue in all organisations across all economic sectors that wish to preserve their position in the market in the future. However, organisations report great difficulty in measuring talent accurately, reflecting the lack of theoretical foundations for talent-identification in practice in area of talent management.

Ledford and Kochanski (2004) and Meyers and van Woerkom (2014) argue that in order for the concept of talent management to be effectively applied, differentiation or segmentation is crucial. It is therefore characteristic of this exclusive approach that only individuals who in some way offer an above-standard benefit to the organisation are included in talent programmes (Pilbeam and Corbridge, 2010; Morton, 2005). According to Stahl et al. (2012) the exclusive approach to talent management is far more common in practice than the above mentioned inclusive approach.

Al Ariss, Cascio and Paauwe (2014) formulated the current trends in talent management, based on their research. In accordance with demographic developments it is possible to expect lower numbers of young employees, and greater numbers of elderly ones. Greater differences between the generations will remain evident.

Cannon and McGee (2011) substantiate importance of talent management, for example, by continuously growing specialisation of staff, growing knowledge, limited flexibility of organisations to start employee education "from scratch", a lack of a matching set of skills and abilities that the organisation finds essential or decreasing flexibility of workers as a result of endeavour to reconcile their family life and career.

A correctly implemented and adequately set system of talent management can be of a number of benefits for both employers and employees. Horvathova (2010) defined the following basic benefits of talent management:

- Talented employees contribute more to accomplishment of the organisation objectives, both economic and strategic ones;

- A reduction is seen in the costs of employee turnover or new employee recruitment;

- Succession for key posts can be planned more efficiently;

- The organisation becomes an attractive employer and its brand is thus being built up;

- It is possible to get employees from in-house resources more efficiently and to improve the design of motivational systems;

- Talented staff are appointed to such posts where their potential is used adequately;

- Loyalty of talented persons grows.

Based on comparison of the contents of definitions of talent and their analyses, Garraldo-Garraldo, Dries and Gonzalez-Cruzc (2013) determined existence of two fundamental approaches to defining the term talent as such - as an object, or as a subject. The former approach conceives a talent as a natural ability of a person, being thus related to characteristics of a human being. From the perspective of the latter approach, a talent is related to people and the definition strives to answer the question of who a talent actually is. In this context, either the inclusive approach is applied, where all the employees without any differentiation are considered talents, or the exclusive one focusing solely on a specific group of employees. Mita Thor International (2015) considers a talent to be such a person who is endowed with extraordinary qualities and is constantly able to perform better than average. He or she also shows a keen interest in a given matter, creativity and self-control ability.

Equally, according to Mpofu and Hlatywayo (2015) or Love and Singh (2011), a talent cannot be associated with certain abilities only. According to the author, this term is also related to personal qualifications, characteristics, creativity, and attitude to work. Hroník (2007) adds that criteria of a talent include respect, performance and prospects for increasing this performance. Ulrich and Smallwood (2012) made a simple formula: 
Talent $=$ competence $\mathrm{x}$ commitment $\mathrm{x}$ contribution

Competencies include the employees' knowledge, skills and values; commitment signals the level of their loyalty to the company and the employees' involvement and their contribution depends on meaningfulness and purpose of their work (Ulrich and Smallwood, 2012). Unlike the above-mentioned attributes, Yarnall (2008), for example, emphasizes such attributes of a talent as efforts, ambition, involvement, or abilities. To identify talents, it is also possible to use, for example, a slightly different threecomponent model which enables companies to identify an employee's potential more efficiently, the components of which are (1) abilities and skills, (2) loyalty, and (3) ambition (Balarin, 2011).

According to the above mentioned the importance of talent management nowadays can be seen in the trend of an aging population which increasingly requires identifying talented employees (from external and internal sources) in organisations who would become the successors of the key employees. After that it is important to ensure knowledge continuity among them. It should be emphasized that managers who are able to identify and respond to the needs of employees can promote the productivity growth of organisation more easily through career management of staff. By means of it they will build good employer's image that is increasingly attracting for further talented employees and helps to retain current talented employees in organisation.

\section{Talents as Determinants of Success of Talent Programmes in Organisation}

Signs of talents can include, for instance, creativity (Turner et al., 2007), or ability to improvise quickly. Berger and Berger (2003) concur, categorising creativity as one of nine representative key competencies that talents should abound with, together with, for example, communication skills, professional qualification, and target orientation. Tatoglu et al. (2016), Evangeline and Gopal Ragavan (2016) state that motivated employees (by means of talent programmes, for instance) use their creativity more, are able to come up with original ideas and introduce innovations in their work. And a lack of creativity or innovative behaviour is often understood as one of the basic causes of failure of an organisation (Yapp, 2009). The same characteristics should be always required from managerial staff that should not only have a creative potential, but also the ability to inspire subordinates and colleagues or the ability to create adequate conditions.

Neber (2004) states, however, that motivational determinants should be more strongly considered and promoted according to the level of development of each man/woman. Swailes and Blackburn (2016), on the basis of their survey, say that employees in talent pools were more positive about their future prospects than employees outside of talent pools who reported feelings of lower support from the organisation, stronger feelings of unfairness, and had lower expectations in terms of what interest the organisation has in them. It can be said that the selection of employees to be included in a talent programme is motivating for them, increasing their work enthusiasm, and they understand it as a possibility to improve their own development. Evangeline and Gopal Ragavan (2016) add that successful management of the employee experience is one of the toughest challenges businesses face today, and they say that by focusing on leveraging the right organisational culture, employing intrinsic as well as extrinsic rewards, companies can improve retention and financial performance, thereby paving way to a healthier competitive advantage. The management of organisations can measure employee sentiment on things such as passion and pride - how passionate employees are about their work, how proud they are to tell people where they work, whether they believe in the mission of the organisation and whether they feel their work is valued and their talents are well utilized.

Even at present time, the Czech society very often works on the basis of orders, bans, or penalties, often lacking preference of personal activity and self-confidence (Vnouckova et al., 2015; Horvathova, 2010).

In this context, organisations do not, unfortunately, realise that growth and self-realisation of talents require new impulses and more challenging tasks all the time (Koubek, 2015) and falling short of this need can be the main impulse for leaving a company.

The staff that are mostly placed in the above-mentioned talent programmes are those in whom the organisation identified a high potential for growth (Malik and Singh, 2014). These programmes can, according to Hroník (2007), speed up career advancement of their participants and increase performance of up to $85-90 \%$ of them. According to Ledford and Kochanski (2004), Garavan et al. (2012), and Sonnenberg et al (2014), several requirements can be characterised on which the correctly designed talent programmes should be based:

- To focus on the staff who really have a talent potential and work with them,

- To standardise talent training courses and monitor and evaluate their efficiency,

- To draw up and then follow short-term plans concerning success achieved,

- To control the corporate HR work with talents,

- To define key competencies of talents, and

- To establish a close link between talent development programmes and the business sphere.

Causes of failure of talent programmes include incorrect talent definition in given organisation, the method of selecting employees for a talent pool, incomprehensible communication, and insufficient information provided to employees (Tatoglu et al., 2016, Swailes and Blackburn, 2016).

The above-mentioned implies that it is not enough for organisations to only identify their talents; they must continue working with this group of employees and guide them correspondingly, and this is exactly what the talent management is about.

For this reason, the article focuses on employment of talents in the Czech Republic as well as on the opportunities that are provided to them, especially with regard to creativity.

\section{Employer Branding and Criteria of its Application}

As the paper is focused on employer's image and branding, it is necessary to mention main criteria and 
grounds in this area. For example, Ind (2003) characterizes employer branding as a holistic process with impact on the way how organisation develops positive employee attitude towards organisation and commitment to job and the entire organisation. Sullivan (2004) broadened the definition by including other stakeholders. Author explains "employer branding" as targeted and long-term strategy, in which organisation aims to positively impact knowledge and awareness of the organisation in the desired direction by employees and other stakeholders and different interest groups (i.e. potential employees and other groups). Employer branding is furthermore defined by Ambler and Barrow (1996) as a sum of three positives - functional, economic, and psychological, which can be closely linked with employer and organisation. Shortly, we may say that it can be considered as an image associated with an organisation from the point of view of its unique role as employer (Knox and Freeman, 2006).

When it comes to the size of organisation and implementation of talent management and employer branding, the study by Buttiens and Hondeghem (2015) showed that those two variables are closely related and implementation of talent management and its related activities (and also of employer branding) may be related to the size of an organisation. This was confirmed also by Egerova et al. (2015) in their research in Central Europe. Furthermore, research made by CIPD (2011) identified significant differences between sectors in which organisation operates and use of talent management and employer branding. Urbancova and Vnouckova (2015) also found that talent management is mostly used in tertiary sector. Furthermore, Van Zyl et al. (2017) add that talent management is extremely important for private sector. In the context of current lack of skilled and talented workers in the job market noticeable preference of inclusive rather than exclusive talent management can be observed (Savaneviciene and Vilciauskaite, 2017). This can lead to a conclusion that the job position obtained - managerial or non-managerial - does not play significant role or any role in placement of employee in talent programme. On the other hand, results of Egerova et al. (2015) show that there is still significant difference in behavior towards an ordinary employee and a manager; thus it is still possible to encounter mostly exclusive approach to talent management and employer branding.

Regarding to the criterion of employee age, most employers state that it does not play important role in employee education and development (Metcalf and Meadows, 2006) and thus it should not affect the process of selectiong employees for development/talent programmes. On the other hand, according to Tiwari and Shrivastava (2013) employee experience may be related to employee age, education, degree, length of employment and type of job position (non/managerial), and employee satisfaction or disaffection with the course and contents of talent programmes.

The above-mentioned criteria are further discussed and investigated it this paper. It is necessary to further analyse the impact and applicability of talent management and employer branding for practical implications and for development of theory.

\section{Materials and Methods}

The paper was prepared based on the method of secondary and primary source analysis, knowledge synthesis, induction, deduction, and comparison. As for secondary sources, scientific monographs and scientific articles in the database of Web of Knowledge and Web of Science dealing with development of key competencies were analysed. Investigation was also made of websites of companies that pursue this issue actively. Primary data were gathered through a quantitative survey, using questionnaires as the method of data collection. The survey was carried out among employees of organisations operating in the Czech Republic.

\section{The Sample}

The sample group of employees consisted of 134 employees. The employees were under a full-time employment contract. The structure of employee respondents addressed was as follows:

- According to size of the organisation they work for: $42.5 \%$ from small, $22.4 \%$ from medium-sized, and $35.1 \%$ from large organisations,

- According to ownership of the organisation they work for: $53.0 \%$ Czech organisations, $14.9 \%$ Czech ones with a foreign owner, and $32.1 \%$ supranational organisations.

Most of the employees, $76.9 \%$ in total, do not hold a managerial post; they are rank-and-file employees. The age structure of respondents is shown in Table 1.

Table 1

Age Structure of Respondents

\begin{tabular}{|c|c|}
\hline Age interval & Relative frequency (\%) \\
\hline $20-24$ years & 24.6 \\
\hline $25-30$ years & 23.1 \\
\hline $31-40$ years & 29.1 \\
\hline $41-50$ years & 14.9 \\
\hline 51 and more & 8.2 \\
\hline Total & 100 \\
\hline
\end{tabular}

$56 \%$ respondents have completed secondary education and $41 \%$ have completed at least a Bachelor degree (university). The employees surveyed have different lengths of their job history; for more detailed information see Table 2 .

Table 2

Employment History of Respondents

\begin{tabular}{|c|c|}
\hline Employment history & Relative frequency (\%) \\
\hline Less than 1 year & 15.7 \\
\hline 1 to 5 years & 44.8 \\
\hline 5 to 10 years & 17.2 \\
\hline More than 10 years & 22.4 \\
\hline Total & 100 \\
\hline
\end{tabular}

\section{Data Processing}

The results were evaluated by descriptive statistic instruments, namely absolute and relative frequency, dependency tests, and dependency force tests. The $\chi^{2}$ test was applied and where the p-value was lower than $\alpha=$ 0.05 , the zero hypothesis was rejected. Additionally, the association analysis was employed to detect a potential dependency among the attributes in question. 
Multidimensional analysis was used to investigate the dependence of two or more variables. The goal of the comprehensive analysis of several variables was to uncover any multidimensional latent data structures and to find an interpretation for these structures. The retrieval of the information in the data file was realized using classic Pearson hypothesis testing, while the classification of the higher levels was achieved using a factor analysis. Firstly, Pearson's correlation and Cramér's V were applied. Factor analysis served a verification role in this paper. The Kaiser-Guttman rule was also applied to select the group of significant factors; based on the recommendations of Anderson (2009), only determinants with an absolute value of more than 0.3 were selected as being significant for factor development.

The processing of the results of the research was performed using IBM SPSS Statistics, version 22. This software is a comprehensive tool for the resolution of statistical tasks and analytical problems. The SPSS software enables the transfer of results to all professional software packets and this also secures the subsequent transferability of the data.

\section{Tested Hypotheses}

A Pearson Chi-Square analysis was used to review the survey output based on the stated results. The following six hypotheses were postulated in order to review the results.

The tested work hypotheses related to Existence and use of talent programme in organisations are stated below:

H1: There is no difference between sector and use of talent programme.

$\mathrm{H} 2$ : There is no difference between the size of an organisation and the use of a talent programme.

H3: There is no difference between managers and employees in terms of participation in talent programmes.

H4: There is no age-based difference in terms of participation in talent programmes.

H5: There is no difference based on education level in terms of participation in talent programmes.

H6: There is no difference based on time of employment in an organisation in terms of participation in talent programmes.

The results evaluating existence of dependency among the defined qualitative attributes are presented in chapter Results.

\section{Results}

Although most of the employee respondents (80\%) say that during their employment in the organisation they are trained (at least once a year) and $95 \%$ of the employee respondents are willing to learn and develop, the current results have shown that mere $18.7 \%$ of the relevant employees of organisations operating in the Czech Republic take part in a talent programme. When compared to other surveys, the number is relatively higher, as many organisations do not apply any talent management at all. Nevertheless, a considerable number of employees are placed in the programmes. This approach has been gradually evolving. Organisations realise that in order to retain good employees it is necessary to develop them, and talent programmes can facilitate both development and retention of such employees.
The results above show that conditions for employee development are still evolving. Moreover, employees themselves realise the necessity of their development. Stagnation threatens their career and employability in organisations (in the current one or even in the next one). It has been found that employees make efforts for their development on their own account, with more than a half of them initiating their own education and development, pursuing them even in their spare time $(70 \%$ of the respondents). They learn and develop for themselves and based on their own decision rather than for other reasons, because most organisations in the Czech Republic (more than two thirds) do not offer many incentives and stimuli for development. In this respect, however, there are substantial differences between organisations. Some organisations encourage and motivate their employees (they are, however, in minority), whereas others do not support employees in any respect.

The employees who are willing to learn and give up even their spare time for development can be expected to develop, because the support and development initiated in the organisation are further developed by a given person. These are the employees that can be called "talents." Investments in education and development of such people will not be wasted (unless the respective employee leaves the organisation) and, on the contrary, they will be rising in value.

Below, results of the defined hypotheses examination will be presented. First, differences related to use of talent programmes, and secondly, determinants of employer's image buliding using Talent programmes, are analysed. The discussion section contains a comparison of the results with regard to the issues in question.

\section{Talent Programme in Organisations}

As it has been mentioned in theoretical background, the talent management and use of talents is currently one of the ways for organisations leading to development, learning, innovations, and overall competitiveness. For this reason, the differences (or even dependencies) among approaches of types of organisations to talent programmes and types of employees and their placement in talent programmes are examined below. These hypotheses are examined to find out whether there is some type of organisations or employers who are closer to the topic under review, or, by contrast, who do not apply these principles. Subsequently, it would be possible to examine what kind of reasons are behind it.

Table 3 (below) shows results of use of talent programmes by the sector in which the organisation operates. However, as evident from the table, the differences are not significant. Even the Pearson's chisquare test (H1) did not identify any differences ( $\mathrm{p}$-value $0.765)$.

Table 3

Employees in Talent Programme per Sector

\begin{tabular}{|l|c|c|c|c|}
\hline \multirow{2}{*}{$\begin{array}{l}\text { Part of talent } \\
\text { programme }\end{array}$} & \multicolumn{3}{|c|}{ Sector } & \multirow{2}{*}{ Total } \\
\cline { 2 - 4 } & primary & secundary & tertiary & \\
\hline Yes & 7 & 5 & 8 & 20 \\
\hline No & 27 & 16 & 45 & 88 \\
\hline Total & 34 & 21 & 53 & 108 \\
\hline
\end{tabular}


In all of the organisations under review, categorised by the sector in which they operate, it has been identified that a minority of their employees are included in a talent programme. It is $20.6 \%$ in the primary sector, $23.8 \%$ in the secondary sector and $15.1 \%$ in the tertiary sector.

Although the talent management is often promoted and tested particularly in organisations in the tertiary sector, the survey results show that here, on the contrary, the lowest percentage of employees are placed in the talent programmes. The primary sector, according to Vnouckova et al. (2015), is more aware of the necessity of retaining good employees, taking into consideration the specifics of work in this sector and the limited choice of employees. The secondary sector is in a similar situation; here the highest percentage of employees in talent programmes has was found.

Subsequently, differences between organisations were examined with regard to the number of their employees. The results are shown in Table 4.

Table 4

Employees in Talent Programme per Organisation Size

\begin{tabular}{|l|c|c|c|c|}
\hline \multirow{2}{*}{$\begin{array}{l}\text { Part of talent } \\
\text { programme }\end{array}$} & \multicolumn{3}{|c|}{ Number of employees } & \multirow{2}{*}{ Total } \\
\cline { 2 - 4 } & $\mathbf{> 2 5 0}$ & $\mathbf{5 0 - 2 4 9}$ & $<\mathbf{5 0}$ & \\
\hline Yes & 12 & 5 & 8 & 25 \\
\hline No & 45 & 25 & 39 & 109 \\
\hline Total & 57 & 30 & 47 & 134 \\
\hline
\end{tabular}

Equally as in categorisation of the organisations by sector, no statistically significant differences have been identified for the size of organisations either. The value of the chi-square test $(\mathrm{H} 2)$ is 0.828 . As shown in Table 4, it is clear again that the ratio is very similar for all sizes of organisation. In large organisations (more than 250 employees) the talent programmes are used in $21 \%$ of the cases, in medium-sized organisations (50-249 employees) in $16.6 \%$ and in small organisations (up to 50 employees) $17 \%$ of employees are placed in talent programmes. The highert percentage is in case of large organisations because of their higher necessity to train a great number of potential talents who can occupy gradually vacated managerial or specialised posts in the future.

The following table (Table 5) shows results presenting placement in talent programmes depending on whether the employee is a rank-and-file worker or a manager. In that process, managers are expected to be placed in talent programmes more frequently as a result of their necessary further development and succession.

Table 5

Employees in Talent Programme According to Position

\begin{tabular}{|l|c|c|c|}
\hline \multirow{2}{*}{$\begin{array}{l}\text { Part of talent } \\
\text { programme }\end{array}$} & \multicolumn{2}{|c|}{ Position } & \multirow{2}{*}{ Total } \\
\cline { 2 - 3 } & Manager & Employee & \\
\hline Yes & 10 & 15 & 25 \\
\hline No & 21 & 88 & 109 \\
\hline Total & 31 & 103 & 134 \\
\hline
\end{tabular}

When examining the differences in placing employees and managers in a talent programme, statistically significant differences have been identified. Managers are placed in talent programmes more frequently than rankand-file workers (H3, the chi-square p-value is 0.027$)$. The examined sample includes $32.2 \%$ of managers placed in talent programmes and only $14.3 \%$ of rank-and-file employees.

Additionally, examination also concerned a dependency between a position and a placement in talent programmes. A low dependency appeared here, with association coefficient of 0.188 . It is probable that managers will be placed in a talent programme; it is one of the main influencing factors.

This result was expected; however, the question is whether it might not be necessary in the future to include more rank-and-file employees for the sake of training line managers.

The next examined hypothesis was the age of employees. Nevertheless, the chi-square test has confirmed that age categories do not show any statistically significant differences $(\mathrm{H} 4$, the chi-square p-value is 0.767 ; the value of the association coefficient is 0.116 ). Therefore, the age does not play any significant role in placing employees in talent programmes. Both younger employees (from 20 years of age) and those at older age (50+) are included.

In terms of placing employees in talent programmes according to their education, no statistical differences have been found. Neither the chi-square test identified any significant differences ( $\mathrm{H} 5$, the chi-square $\mathrm{p}$-value is $0.665)$.

This means that the highest level of education completed does not have a principal influence on placement of employees in talent programmes. Although only one employee with elementary education was placed in the talent programme, there is no substantial difference in case of secondary and tertiary education. In the sample of employees placed in a programme, $16 \%$ were university graduates and as many as further $21.8 \%$ were secondary school graduates with no university degree. As the survey results show, the work with employees in talent programmes concerns more those with secondary education. They likely have greater potential for further development than university graduates who are already largely shaped by their university studies.

The last examined hypothesis related to talent programmes in organisations was the time spent at the organisation. However, this also plays no fundamental role in placing employees in talent programmes (H6, the chisquare p-value is 0.953). Both newly hired employees (up to one year at the organisation) and employees who have been at the organisation for a longer time are placed in talent programmes. No exception to the rule is represented even by those who have been working in the organisation for their entire life (more than 15 years).

It can be concluded that the results of the examination showed a dependency only in case of the position held in the organisation and placement in talent programmes. Other demographic characteristics of employees, such as age, education, and time spent at the organisation, do not play any role in placing in talent programmes. On the contrary, with respect to these characteristics it can be concluded that all types of employees are placed in these programmes.

\section{Buliding Employer's Image Using Talent Programmes}

The chapter deals with further evaluation of the concept of talent programmes and its use in the studied organisations 
in the Czech Republic. Main focus is on criteria of employer branding.

Factor analysis was used to analyze the results in more depth. First, a correlation analysis was conducted. Given that sufficient quantity and quality of correlation coefficients was found in the correlation table, a subsequent analysis was conducted: i.e. factor analysis. According to the evaluation of the calculated data, a total of 5 significant factors were identified following evaluation of the survey. Three of them only slightly exceeded the value of 1.0 and for this reason were eliminated from further assessment. In total, therefore, 2 significant factors were identified that meet the criteria according to this methodology. To make calculations of factor analysis, the final table was adjusted to leave out variables that were repeated in the factors and did not form a unique factor composition. In addition, variables that hardly reached the required minimum values in order to be included in factors were omitted. The specific identified factors and their descriptions are given below (Table 6). Significant attributes for the given factor are highlighted in bold. A total of $63.343 \%$ of variance was explained.

Table 6

\section{Attributes of Employer Branding}

\begin{tabular}{|c|c|c|}
\hline Attributes & Factor 1 & Factor 2 \\
\hline $\begin{array}{l}\text { External workers are attracted and wish } \\
\text { to work in the organisation }\end{array}$ & .551 & .061 \\
\hline $\begin{array}{l}\text { Organisation is attractive for talented } \\
\text { workers }\end{array}$ & .542 & -.099 \\
\hline $\begin{array}{l}\text { Research \& development is financed in } \\
\text { organisation - growing }\end{array}$ & .538 & -.145 \\
\hline $\begin{array}{l}\text { Research \& development is not } \\
\text { financed; managed randomly }\end{array}$ & -.176 & .549 \\
\hline $\begin{array}{l}\text { Innovations are created and } \\
\text { implemented in organisation }\end{array}$ & .496 & .001 \\
\hline $\begin{array}{l}\text { Organisation motivates for } \\
\text { development }\end{array}$ & .671 & -.005 \\
\hline $\begin{array}{l}\text { Organisation supports employees with } \\
\text { coaches and mentors }\end{array}$ & .627 & .056 \\
\hline $\begin{array}{l}\text { Managers cooperate with employees in } \\
\text { area of development }\end{array}$ & .713 & .058 \\
\hline $\begin{array}{l}\text { System of development is not } \\
\text { transparent }\end{array}$ & -.161 & .595 \\
\hline Total Variance & 4.075 & 1.626 \\
\hline$\%$ Variance & 45.27833 & 18.06467 \\
\hline Name of the factor & $\begin{array}{l}\text { Strategic } \\
\text { employer } \\
\text { branding }\end{array}$ & $\begin{array}{c}\text { Lack of } \\
\text { development } \\
\text { transparency }\end{array}$ \\
\hline
\end{tabular}

The first factor is formed by 7 variables that are typical for the area of the integration of employer branding with the strategic goals of the organisation. According to the attributes represented by Factor 1, which are focused on the "organize and manage" concepts of human resources development together with development of organisation, as well as the alignment of development objectives with company objectives. This factor may be called "Strategic employer branding". It can be stated that $45.3 \%$ of the sample examined have a very good concept of employer branding and human resources management, which significantly correlates with attraction of external workers and talents. Likewise, these organisations work with research and development and they have special budget for it; innovations are created and regulary implemented, employees are motivated for development and supported by coaches and mentors, which in sum attracs externals workers and talents.

As mentioned in the theoretical backgrounds, there are interconnections between talent management and building of a strong and positive image of the employer thanks to which talented individuals may be attracted and retained. The factor analysis discovered single attributes of branding in human resources management which are used and are strongly connected to strategic employer marketing.

Strategic employer marketing may be defined by the following: Firstly, by acknowledged importance of essential management practice, secondly, by focus on research and development in organisation and thirdly, by development of employees by mentors and coaches employed by the organisation to create its image as desirable employer in the eyes of prospective employees.

Such practices are crucial parts of a successful strategic approach to employer branding. This factor is predominantly composed of systematic evaluation of research and development, clearly defined criteria for development of employees, as well as formulation of conclusions from employee development evaluations.

The second approach of studied organisations to talent programmes and employer branding is directly opposite. It may be characterized by a lack of methods for the connection of talent development and talent programmes; neither research nor development is specified and managed; transaprency of system is also not obvious. Organisations grouped in the factor are not aware of the necessity of talents and development in the future. So, they systematically ignore research and development, do not manage it, and do not care about employee development; development plans are missing. Talent programmes are not used or specified, or they are not transparent. The assessment of talents and the criteria for integration in talent programme are not specified in these organisations. Plus, external workers are not attracted by such organisations. In total, $18.1 \%$ of the studied sample can be described as lacking development and transparency of the system of talent programmes.

It is possible to summarize the survey as follows. 45.3 $\%$ of surveyed organisations use strategic employer branding. The factor description clearly specifies the practices connected to strategic employer branding. The other part does not focus on the development of organisation or employees, talent programmes are not specified and the main attributes of employer branding are not used.

The results clearly defined key components of strategic employer branding: growing budget on research and development in the organisation, implementation of innovation, motivation of employees for development, support of coaches and mentors in the organisation, and cooperation of managers on employee development.

It is possible to mention the overall impact of employer branding on the talent programmes and HR strategy of an organisation. The results show that development activities in human resource practices are managed by the organisations which are aware of the whole organisational development and necessity to attract external talents and workers. The survey also analysed other human resource practices used and connected to talent programmes. However, the statistical tests revealed 
significant correlations mainly between development of organisation using talent programmes, and attractivity of an organisation for external talents and workers and thus building employer's image. It is thus necessary for management of organisations to be an active partner of the human resource department, to support talent management processes and programmes, and to work on the application of employer branding such as research and development processes. The benefits of talent programmes would not otherwise make a significant contribution to an organisation. The specification of strategic employer branding may be seen in the ability of management to share the importance of the concept of employer branding throughout the whole organisation and job market. The management of organisations must be able to incorporate practices and concepts of employer branding into the vision and mission of an organisation as well as to define its strategy and to integrate it into the strategic goals of the organisation, and also to create a list of key talents and planned promotions in talent programmes.

The whole process of building employer's image is therefore underpinned by the relationship between managers and their subordinates at the higher levels of an organisation and subsequently with those at the lower levels. Talent programmes and their practices were found to be personal, depending on the development of each individual, and also on research and development in the organisation. The results identify the specificities of using talent programmes for building employer's image as compared to other human resource practices. There is a clear reference to systematic work with employees as individuals using specified plans of development and assessment, and also to work on processes in the organisation related to research and development.

The results show that employees who are interested in their development also look for a similar-minded employer. It is necessary to prepare conditions for the knowledge employees or talents, because they purposefully search for and start working in organisations with the precise aim of developing. If the employer is attractive, employees of this kind search for him/her themselves and are interested in working in such organisation. However, if the organisation does not enable further education and development of these employees, they will look for another job where their requirements are met.

\section{Discussion}

As it has been already mentioned in the theoretical backgrounds of the paper, it is nowadays difficult for organisations to define talent as a term and clearly specify talent management at the organisation level. Although these terms are currently a topic highly discussed in practice in the Czech Republic, we can say that a single specification and definition of these terms still do not still exist among experts. With Koubek (2015) it can be stated that talent management in Czech organisations currently focuses on key persons only, capable and aiming for higher posts, which is also shown by the conclusions of the presented results regarding the sample group of employees. However, in the future, when competition in the labour market will continue growing keener, this approach cannot be considered correct. It can be stated that along with the growing globalisation, change in the demographic structure of the population, more rapid changes, and keen competition in the labour market, it is necessary to consider every employee who is able to assist in achieving objectives of the organisation to be a talent. Nevertheless, to what extent a talented person can contribute to accomplishment of the organisation targets depends primarily on the efforts of the organisation management, on what importance they attach to talent growth and development, and on what talent programmemes they create to be attractive for both existing and potential employees.

The employees who took part in the survey are willing to learn and interested in making use of such opportunity. In their current position, $95.5 \%$ of the respondents are interested in personal growth. Employees appreciate opportunities for development, education, or training, and consider them to be part and parcel of their job. This is good news for organisations, since employee motivation is generally high and it is thus easier to work on education and training of such employees. In-house learning advantages can be summarised in two basic categories: career advancement and psychological support (Beech and Brockbank, 1999; Gannon and Maher, 2012). As one theory claims, the key to effective learning of adults is their intrinsic motivation (Evangeline and Gopal Ragavan, 2016). At present, employees perceive the modern trend of necessary flexibility and they therefore want to make use of the opportunity for personal growth. Swailes and Blacburn (2016) and Tatoglu et al. (2016) also state that there is no sense in motivating employees; instead, an environment should be created in which they become selfmotivated. Equally, employees are aware of the fact that they will usually not spend their entire life in one job and they want to test their knowledge and skills to succeed professionally, regardless of whether in their current position or in the next one (Linhartova, 2012).

Regarding the criteria related to application of talent management and employer branding, the conducted study found that there is no statistically significant link between the size of an organisation and the implementation of talent management and employer branding; furthermore, there are no statistically significant differences between sectors in use of talent programmes. This result is contrasting with finding of study by Buttiens and Hondeghem (2015) who stated that implementation of talent management (and also employer branding) may be related to the size of an organisation. The present study found that talent management is on its rise and most of the organisations across sectors are aware of or pay attention to talent development and know its importance. It is further connected to current context of lack of skilled and talented workers in the job market, as mentioned also by Savaneviciene and Vilciauskaite (2017).

The presented results also lead to a conclusion that the acquired job position - managerial or non-managerial plays a significant role in placement of employee in a talent programme, a fact also supported by results of Egerova et al. (2015). We may state that there remains a significant difference in behavior towards ordinary employees and managers. There are continuos differences in approaches towards talent management and employer branding. 
We may also mention the criterion of employee age. As stated in the theory, most of the employers do not perceive age as affecting employee education and development (i.e. Metcalf and Meadows, 2006). Our study revealed the same outcomes. Statistical tests confirmed that age does not affect placement in talent programme.

Every programme defined for talents has to be motivating for employees - not only for the employees currently included in the talent programme, but also for other potential participants. On the other hand, it is important for the current employees in the talent programme to know that they must continue working on themselves, developing and meeting the criteria of the talent programme that have been defined by the organisation management. It is necessary to continuously encourage healthy competition that results in a boost to creativity. At present, creativity is a highly regarded quality of employees and this quality is innate; however, it can be learnt and strengthened by development, but the degree and intensity of the development are important. Hospodařova (2008) says that creativity is an instrument for surveying in the current competitive environment, as every person faces the necessity to solve problems in personal life and at work on a daily basis.

\section{Conclusions}

The results of the study carried out show that employees are aware of the necessity to learn and develop and therefore it is actually easier for organisations to get employees to these processes. They try to learn themselves; however, they need to be supported and developed. If the organisation management creates conditions for them and continues guiding them and controls the education and development process, the results reach synergic effects. In general, the results have shown that most employees want to take part in the education and learning process and are aware of its necessity. One positive finding is that employees are often self-motivated and look for new ways of growth. Motivation of top management for talent management application is pushed by society-boundness of the organisation, which is confirmed by the results of Tatoglu et al. (2016). Additionally, employees in talent pools are more positive and motivated about their future prospects than employees outside talent pools. It can be said that the selection of employees to the talent programme is motivating for them and increases their enthusiasm to work, and that they understand it as opportunity to improve their own development and performance, which also affects organisation.

The extension of the theory may be seen in the specification of succeful employer branding. Multidimensional statistics found two types of organisations related to use of talent programmes to bulid employer's image. Firstly, organisations focused on HR marketing were found, and secondly, lack of transparency in employer's branding was described. The outputs alow us to define crucial components of succesfull employer branding. These are growing budget on research and development in organisation, implementation of innovation, motivation of employees for development, support of coaches and mentors in the organisation, and cooperation of managers on employee development.

In view of the results it can be stated that by welldefined talent programmes an organisation can build its brand as an employer and can get talents already in the labour market.

Limits of the article can be seen in a relatively small sample of respondents (employees), but as, for the time being, organisations in the Czech Republic prefer an exclusive approach to talent management, when only a small percentage of organisation employees are placed in talent programmes (after meeting the defined criteria) and most organisations do not pursue talent management, the sample of 134 employees from 134 organisations can be described as sufficient and representative. Nevertheless, the results can be applied generally to the sample of respondents - organisations operating in the Czech Republic. The survey in the Czech Republic will be subsequently repeated, with a focus on satisfaction of individual employees with the contents of talent programmes that organisations offer to their employees.

\section{Acknowledgement}

This contribution is a follow-up to the project of University of Economics and Management and of the University - wide internal grant agency (CIGA), number 20141002 - Human Resource Branding Using of the New Strategic Trends in Organizations in the Czech Republic.

\section{References}

Al Ariss, A., Wayne, F. C., Paauwe, J. (2014). Talent management: Current theories and future research directions. Journal of World Business, 49, 173-179. https://doi.org/10.1016/j.jwb.2013.11.001

Ambler, T., \& Barrow, S. (1996). The employer brand. Journal of brand management, 4(3), $185-206$. https://doi.org/10.1057/bm.1996.42

Backhaus, K., Tikoo, S. (2004). Conceptualizing and researching employer branding. Career Development International, 9(5), 501-517. https://doi.org/10.1108/13620430410550754

Balarin, D. (2012). Ten years after: Talent Management. HR Forum. Available from internet: http://www.hrforum.cz/deset-let-pote-talent-management/.

Beech, N., Brockbank, A. (1999). Power/knowledge and psychosocial dynamics in mentoring. Management Learning, 30(7), 7-25. https://doi.org/10.1177/1350507699301002 
Berger, L. A., Berger, D. R. (2003). Talent management handbook: Creating organizational excelence by identifyimg, developing \& promoting your best people. New York, NY: McGraw- Hill.

Brewster, C., Sparrow, P., Harris, H. (2005). Towards a new model of globalizing HRM. The International Journal of Human Resource Management, 16, 949-970. https://doi.org/10.1080/09585190500120590

Burawat, P. The relationship among perceived employer branding, employee engagement and employee expectation in service industry. International Business Management, 9 (4), 554-559.

Buttiens, D., \& Hondeghem, A. (2015). Strategic choices regarding talent management in the Flemish public sector. Society and Economy, 37(1), 49-72. https://doi.org/10.1556/SocEc.37.2015.1.3

Cannon, J. A., McGee, R. (2011). Talent Management and Succession Planning. London, UK: Chartered Inst. of Personnel and Development.

CIPD. (2011). Employment relations survey. Chartered Institute of Personnel and Development. Available from internet: https://www.cipd.co.uk/knowledge/fundamentals/relations/employees/survey-report.

Chapman, D., Uggerlev, K., Carroll, S., Piasentin, K. Jones, D. (2005). Applicant attraction to organizations and job choice: a meta- analytic review of the correlates of recruiting outcomes. Journal of applied psychology, 90, 928944. https://doi.org/10.1037/0021-9010.90.5.928

Cheese, P., Craig, E., Thomas, R. (2008). The talent powered organization : strategie for globalization, talent management and high performance. London, UK: Kogan Page.

CSR Forum. (2011) Available at http://zpravy.aktualne.cz/ekonomika/britanie-hleda-talent-vi-ze-jen-tak-ochraniekonomiku/r i:article:693201/

Collings, D. G., Mellahi, K. (2009). Strategic talent management: A review and research agenda. Human Resource Management Review, 19, 304-313. https://doi.org/10.1016/j.hrmr.2009.04.001

Deb, T. (2006). Strategic Approach to Human Resource Management. New Delhi, IND, Atlantic Publishers \& Dist.

Dell, D., Hickey, J. (2002). Sustaining the Talent Quest: Getting and Keeping the Best People in Volatile Times. The Conference Board.

Edwards, M., R., Edwards, T. (2013). Employee responses to changing aspects of the employer brand following a multinational acquisition: a longitudinal study. Human Resource Management, 52(1), $27-54$. https://doi.org/10.1002/hrm.21519

Egerova, D. Et al. (2013). Integrated talent management: challenge and future for organizations in Visegrad countries. Plzeň, CZ: Nava.

Egerova, D., Lancaric, D., Eger, L., \& Savov, R. (2015). Perspectives of talent management: evidence from czech and slovak business organisations. E+ M Ekonomie a Management, (4), 108-120. https://doi.org/10.15240/tul/001/20154-008

Evangeline, E. T., Gopal Ragavan, V. P. (2016). Organisational culture and motivation as instigators for employee engagement. Indian Journal of Science and Technology, 9(2), 4pp. https://doi.org/10.17485/ijst/2016/v9i2/86340

Farndale, E., Pai, A., Sparrow, P., Scullion, H. (2014). Balancing individual and organizational goals in global talent management: A mutual-benefits perspective. Journal of World Business, 49(2), $204-214$. https://doi.org/10.1016/j.jwb.2013.11.004

Festing, M, Schäfer, L. (2014). Generational challenges to talent management: A framework for talent retention based on the psychological-contract perspective. Journal of World Business, 49(2), $262-271$. https://doi.org/10.1016/j.jwb.2013.11.010

Fernandez-Lores, S., Gavilan, D., Avello, M., Blasco, F. (2016). Affective commitment to the employer brand: Development and validation of a scale, Business Research Quarterly, 19(1), 40-54. https://doi.org/10.1016/j.brq.2015.06.001

Gallardo-Gallardo, E., Dries, N., \& Gonzalez-Cruze, T. F. (2013). What is the meaning of 'talent' in the world of work? Human Resource Management Review, 23(4), 290-300. https://doi.org/10.1016/j.hrmr.2013.05.002

Gannon, J. M., Maher, A. (2012). Developing tomorrow's talent: the case of an undergraduate mentoring programme. Education + Training, 54(6), 440-455. https://doi.org/10.1108/00400911211254244

Garavan, T. N., Carbery, R., Rock, A. (2012). Mapping talent development: definition, scope and architecture. European Journal of Training and Development, 36, 5-24. https://doi.org/10.1108/03090591211192601

Horvathova, P. (2010). Talent Management and its Using in Human Resource Management in Organizations. Ekonomic Revue, 13, 77-95. 
Lucie Vnouckova, Hana Urbancova, Helena Smolova. Building Employer Image Thanks to Talent Programmes in ...

Hroník, F. (2007). Development and training and learning. Prague, CZ: Grada Publishing.

Ind, N. (2003). Inside out: How employees build value. Journal of Brand Management, 10(6), 393-402. https://doi.org/10.1057/palgrave.bm.2540136

Jain, N., Bhatt, P. (2015). Employment preferences of job applicants: Unfolding employer branding determinants. Journal of Management Development, 34(6), 634-652. https://doi.org/10.1108/JMD-09-2013-0106

Jiang, T., Iles, P. (2011). Employer-brand equity, organizational attractiveness and talent management in the Zhejiang private sector, China. Journal of Technology Management in China, 6, 97-110. https://doi.org/10.1108/17468771111105686

Kim, J., York, K. M., Lim, J. S., (2011). The role of brands in recruitment: A mixedbrand strategy approach, Marketing letters, 22(2), 165-179. https://doi.org/10.1007/s11002-010-9119-9

Knox, S., \& Freeman, C. (2006). Measuring and managing employer brand image in the service industry. Journal of Marketing Management, 22(7-8), 695-716. https://doi.org/10.1362/026725706778612103

Kocianova, R. (2012). Human Resource Management, Prague, CZ: Grada Publishing.

Koubek, J. (2015). Human Resource Management. Prague, CZ: Management Press.

Kwon, W. J. (2014). Human capital risk and talent management issues in the insurance market: Public policy, industry and collegiate education perspectives. Geneva Papers on Risk and Insurance: Issues and Practice, 39 (1), $173-196$. https://doi.org/10.1057/gpp.2013.11

Love, L. F., Singh, P. (2011). Workplace Branding: Leveraging Human Resources Management Practices for competitive Advantage Through Best Employer Surveys, Journal of Business and Psychology, 26(2), $175-181$. https://doi.org/10.1007/s10869-011-9226-5

Leary-Joyce, J. (2011). Psychology of the success. Brno, CZ: Computer Press.

Ledford, G., Kochanski, J. (2004). Allocating training and development resources based on contribution. In Berger L., Berger D. (Eds.). The Talent Management Handbook, pp. 218-229. New York, USA: McGraw-Hill.

Linhartova, L. (2012). Variability of Employees' Behaviour during Disaffection. Ekonomický casopis, 60(1), 83-97.

Malik, A. R., Singh, P. (2014). 'High potential' programs: Let's hear it for 'B' players. Human Resource Management Review, 24(4), 330-346. https://doi.org/10.1016/j.hrmr.2014.06.001

Martin, G., Gollan, P. J., Grigg, K. (2011). Is there a bigger and better future for employer branding? Facing up to innovation, corporate reputations and wicked problems in SHRM, International Journal of Human Resource Management, 22(17), 3618-3637. https://doi.org/10.1080/09585192.2011.560880

Metcalf, H., \& Meadows, P. (2006). Survey of employers' policies, practices and preferences relating to age. Corporated Document Services.

Meyers, M. C., van Woerkom, M. (2014). The influence of underlying philosophies on talent management: Theory, implications for practice, and research agenda. Journal of World Business, 49, $192-203$. https://doi.org/10.1016/j.jwb.2013.11.003

Mita Thor International (2015). Employees stabilization. Available from internet: http://www.mitathor.cz/stabilizacepracovniku.php

Mpofu, M., Hlatywayo, C. K. (2015). Training and development as a tool for improving basic service delivery; the case of a selected municipality. Journal of Economics, Finance and Administrative Science, 20(39), 133-136. https://doi.org/10.1016/j.jefas.2015.10.004

Mohr, D. C., Young, G., J., Burgess, J. F. (2012). Employee turnover and operational performance: the moderating effect of group-oriented organisational culture, Human Resource Management Journal, 22(2), $216-233$. https://doi.org/10.1111/j.1748-8583.2010.00159.x

Neber, H. (2004). Teacher Nomination for an Enrichment Program as an Example of Talent Search in College Prep Courses. Psychologie in Erziehung und Unterricht, 51(1), 24-39.

Nijs, S., Gallardo-Gallardo, E., Dries, N., Sels, L. (2014). A multidisciplinary review into the definition, operationalization, and measurement of talent. Journal of World Business, 49(2), 180-191. https://doi.org/10.1016/j.jwb.2013.11.002

Pilbeam, S., Corbridge, M. (2010). People resourcing and talent planning: HRM in practice. Harlow, UK: Pearson Education.

Savaneviciene, A., \& Vilciauskaite, B. (2017). Practical Application of Exclusive and Inclusive Talent Management Strategy in Companies. Business, Management and Education, 15(2), 242. https://doi.org/10.3846/bme.2017.366 
Silzer, R. F., Dowell, B. E. (2010). Strategy-driven talent management: a leadership imperative. San Francisco, USA: Jossey-Bass.

Stahl, G. K., Bjorkman, I., Farndale, E., Morris, S. S., Paauwe, J., Stiles, P. (2012). Six principles of effective global talent management. MIT Sloan Management Review, 53, 24-32.

Sturman, M. C., Shao, L., Katz, J. H. (2012). The effect of culture on the curvilinear relationship between performance and turnover, Journal of Applied Psychology, 97(1), 46-62. https://doi.org/10.1037/a0024868

Sonnenberg, M., Van Zijderveld, V., Brinks, M. (2014). The role of talent-perception incongruence in effective talent management. Journal of World Business, 49(2), 272-280. https://doi.org/10.1016/j.jwb.2013.11.011

Sullivan, J. (2004). Eight elements of a successful employment brand. ER Daily, 23(2), 501-517.

Swailes, S., Blackburn, M. (2016). Employee reactions to talent pool membership. Employee Relations, 38(1), $112-128$. https://doi.org/10.1108/ER-02-2015-0030

Flahive, T. (2015). A practical tool to measure ROI (Return on Investment) on any leadership programme, In Society of Petroleum Engineers - SPE Kuwait Oil and Gas Show and Conference.

Tatoglu, E. A., Glaister, A. J., Demirbag, M. C. (2016). Talent management motives and practices in an emerging market: A comparison between MNEs and local firms. Journal of World Business, 51(2), $278-293$. https://doi.org/10.1016/j.jwb.2015.11.001

Tiwari, U., \& Shrivastava, D. (2013). Strategies and practices of talent management and their impact on employee retention and effectiveness. The International Journal of Management, 2(4), 1-10.

Turner, P., Tansley, C., Foster, C., Harris, L., Stewart, J., Sempik, A., Williams, H. (2007). Talent management: the executive view. London, UK: Chartered Inst. of Personnel and Development.

Ulrich, D., Smallwood, N. (2012). What is talent? Michigan Ross School for Business - Executive White Paper Series. Available from internet: https://michiganross.umich.edu/sites/default/files/uploads/RTIA/pdfs/dulrich_wp_what_is_talent.pdf

Urbancova, H., \& Vnouckova, L. (2015). Investigating talent management philosophies. Journal of Competitiveness, 7(3), 3-18. https://doi.org/10.7441/joc.2015.03.01

Van Zyl, E. S., Mathafena, R. B., \& Ras, J. (2017). The development of a talent management framework for the private sector. SA Journal of Human Resource Management, 15(1), 1-19. https://doi.org/10.4102/sajhrm.v15i0.820

Vnouckova, L., Urbancova, H., Smolova, H. (2015). Possibilities of Talent Development in the Czech Republic. Agrarian Perspectives. Praha: Czech University of Life Sciences, 519-527.

Yarnall, J. (2008). Strategic Career Management: Developing Your Talent. Burlington, MA: Butterworth-Heinemann.

Yapp, M. (2009). Measuring the ROI of talent management. Strategic HR Review, 8(4), 5-10. https://doi.org/10.1108/14754390910963856

Wilden, R., Gudergan, S., Lings, I. (2010). Employer branding: strategic implications for staff recruitment. Journal of Marketing Management, 26, 56-73. https://doi.org/10.1080/02672570903577091

The article has been reviewed.

Received in January, 2016; accepted in May, 2018. 